\title{
Value of Peak Cough Flow (PCF) in Healthy Middle Adulthood and Late Adulthood and the Affecting Factors
}

\section{Nury Nusdwinuringtyas ${ }^{1}$, Roy Dwi Indra ${ }^{1}$, Tresia Fransiska Ulianna Tambunan ${ }^{1}$, Aria Kekalih ${ }^{2}$}

${ }^{1}$ Rehabilitation Medicine Department, Medicine Faculty, University of Indonesia, Jakarta, Indonesia.

${ }^{2}$ Comunity Medicine Department, Medicine Faculty, University of Indonesia, Jakarta, Indonesia.

\begin{abstract}
Introduction: Cough is a symptom that is felt by all humans and it is important for the protection which maintains mucus secretion, foreign substances, and infections of the larynx, trachea and bronchi. The purpose of this study is to find out the PCF value in healthy middle adulthood and late adulthood and the factors that influence it.

Methods: This study is a cross-sectional study involving 99 subjects. Subjects were patients in the clinic for medical rehabilitation of middle adulthood and late adulthood healthy respiration. Subjects who fulfilled the inclusion and exclusion criteria were examined with spirometry to ensure healthy respiration and after that, the PCF examination was carried out with a peakflowmeter device and the correlation was observed with age, gender and, height.

Results: The PCF value in healthy middle adulthood is $190-540 \mathrm{~L} /$ minute $(41-50$ years $465 \mathrm{~L} /$ minute, ages 51-60 years $405 \mathrm{~L} /$ minute) and healthy late adulthood is $245-520 \mathrm{~L} /$ minute with median 352.5 L / minute. Men have a greater PCF value than women, but at the age of 61 years and over there not significantly different. The higher age, the lower the PCF value obtained and there was a statistically significant decrease in the PCF value at 61-70 years of age compared to 41-50 years of age. Subjects with high height have a tendency for a larger PCF value and height will affect the PCF value.

Conclusion: Obtained PCF values in middle adulthood and late adulthood with healthy respiration and there is a relationship between sex, age and height factors for the PCF value.
\end{abstract}

Keywords: Age, height, Peak Cough Flow, peakflow meter, sex. 


\section{ABSTRAK}

Pendahuluan: Batuk adalah gejala yang dirasakan oleh semua manusia dan penting untuk perlindungan dan perlindungan yang menjaga dari sekresi lendir, zat asing, dan infeksi pada laring, trakea, dan bronkus. Tujuan penelitian ini adalah untuk mengetahui nilai PCF pada orang dewasa dewasa menengah dan lanjut sehat serta faktor-faktor yang mempengaruhinya.

Metode: Penelitian ini merupakan penelitian cross-sectional yang melibatkan 99 subjek. Subjek penelitian adalah pasien di klinik untuk rehabilitasi medis usia dewasa menengah dan pernapasan sehat orang dewasa lanjut. Subjek yang memenuhi kriteria inklusi dan eksklusi diperiksa spirometri untuk memastikan respirasi yang sehat dan setelah itu pemeriksaan PCF dilakukan dengan alat peak flow meter dan korelasi diamati dengan usia, jenis kelamin dan tinggi badan.

Hasil: PCF pada orang dewasa madya sehat antara 190-540 L / menit ( 41-50 tahun 465 L / menit, usia 51-60 tahun 405 L/menit ) dan dewasa lanjut sehat antara 245-520 L/menit dengan nilai tengah 352,5 L / menit. Pria memiliki nilai PCF yang lebih besar daripada wanita, tetapi pada usia 61 tahun ke atas PCF pria tidak berbeda secara signifikan dari wanita. Semakin tinggi usia, semakin rendah nilai PCF yang diperoleh dan ada penurunan nilai PCF yang signifikan secara statistik pada usia 61-70 tahun dibandingkan dengan usia 41-50 tahun. Subjek dengan tinggi tinggi memiliki kecenderungan untuk nilai PCF yang lebih besar dan tinggi akan mempengaruhi nilai PCF.

Kesimpulan: Memperoleh nilai PCF pada orang dewasa madya dan dewasa lanjut sehat respirasi dan ada hubungan antara jenis kelamin, faktor usia dan tinggi untuk nilai PCF.

Kata Kunci: $P C F$, peak flow meter, usia, jenis kelamin, tinggi badan.

\section{Correspondent Detail:}

\section{Nury Nusdwinuringtyas}

Email: nury_nus@yahoo.com

Department of Physical Medicine and

Rehabilitation, Dr. Cipto Mangunkusumo

Hospital, University of Indonesia,

Jakarta, Indonesia

\section{INTRODUCTION}

Cough is a symptom that all humans feel and it's vital for protection that protects the process of removing mucus, foreign substances, and infections of the larynx, trachea and bronchi. Coughing becomes the most efficient mechanism for cleansing the upper airway and can be called a defense mechanism in the body. Disruption or absence of a coughing mechanism can be disruptive and/ or dangerous in sickness. Coughing depends on the strength of the respiratory muscles, especially on the strength of the inspiring muscles. The method used for cough evaluation is obtained by measuring the Peak Cough Flow (PCF).

PCF is the most reliable way to evaluate cough strength, measured using a peak flow meter 
(PFM). ${ }^{6}$ In middle adulthood, the age between 41-60 years begins the aging process compared with young adults (18-40 years) on the small airway and alveoli, after the age of 50, there is an increased incidence of degeneration of elastin fibers in the bronchioles of the lungs and alveoli. Collagen fibers in the lung parenchyma will exceed the amount of elastin.

This causes a lack of lung elasticity and increased rigidity of the chest wall. Also, there is a decrease in strength and endurance of the respiratory muscles, which reduces the maximum pressure of inspiration (from the age of 20) and expiration (from the age of 50) so that the vital lung capacity and cough function decline. ${ }^{4}$ In late adulthood ( $>60$ years), there is a change in the respiratory system compared to young and middle adulthood. Changes that occurred in the form of decreased lung elastic recoil and thoracic compliance capacity and decreased respiratory muscle strength which will result in decreased APE and can result in decreased coughing ability resulting in decreased PCF value. ${ }^{4}$

There have been many studies on the PCF value in healthy young adults, but the PCF value in healthy middle adulthood and late adulthood has not been much studied. Freitus et al (2010) say the average PCF value in healthy late adulthood in Brazil is $309.2 \mathrm{~L} /$ minute in women and 434.4 $\mathrm{L} /$ minute in man. There is still no research for PCF value in healthy middle and late adulthood in Indonesia.

In their study, Lee et al. (2015) said the average PCF value of Caucasian races in England was 652 $\mathrm{L} / \mathrm{min}$. Fauzan (2016) said the PCF value in young adults in Indonesia (Mongoloid race) ranged from 310-645 L / min, with PCF values in men between
463 - $607 \mathrm{~L} / \mathrm{min}$ and in women $366-472 \mathrm{~L} /$ min and found a decrease in PCF value along with increasing age. In both races, there was a significant difference in the PCF value. This is because there were differences in average height in the UK (average $177.6 \mathrm{~cm}$ ) and Indonesia (average 158 $\mathrm{cm})$. However, no studies are examining whether gender, age, and height factors significantly influence PCF values in healthy middle adulthood and late adulthood in Indonesia. ${ }^{17,19}$

Healthy individuals based on spirometry examination are individuals whose lung function has no restriction or obstruction in the airways, do not have a history of neuromuscular disease, respiratory system of acute or chronic normal phases, and normal chest expansion measurement to age and sex.

Based on the background above, it is important to know the objective value of healthy individuals' cough function capacity in determining respiration rehabilitation programs. At present, there is no research on the PCF value in healthy middle adulthood and late adulthood, which is important to know as a baseline PCF value in Indonesia. For this reason, researchers conducted a study to determine the PCF value in middle adulthood and late adulthood using PFM tools and the correlation between age, sex and height on the PCF value.

\section{METHOD}

The research design used is cross-sectional to measure the PCF value and the factors that influence it in healthy middle and late adulthood who are analytic because it is tested statistically. The target population is healthy subjects aged 
over 40 years with both parents coming from Indonesia. The affordable population is a subject in the RSCM environment and Jakarta communities that meet the acceptance criteria. Samples that meet the acceptance criteria are not included in the rejection criteria until the number of research samples is met and willing to follow the research by filling out informed consent. Inclusion criteria are. Healthy subject respiration, ages 41-70 years, is willing to participate in research voluntarily by signing the consent form after explanation, having normal cognition (MMSE), no hearing loss, and speaking Indonesian.

Exclusion criteria are subject not able and understanding in the work instructions from technical research, has contraindications for conducting spirometry and PCF checks, namely: abdominal/ thoracic surgery in the last one month, brain, eye and Ear Nose Throat surgery in the last 2-3 months, pneumothorax in the last 2-3 weeks, myocardial infarction in the past one week, aortic aneurysm in the past one week, hemoptysis, pulmonary embolism in the past one week, acute diarrhea, angina, severe hypertension (systolic blood pressure $>200 \mathrm{~mm} \mathrm{Hg}$, diastolic $>120 \mathrm{mmHg}$ ), dementia, infection.

Sample size estimation is using numerical descriptive for men using 51 standard deviations and 38 women based on references. ${ }^{18}$ Absolute error used $5 \%$ of the highest average peak cough current value. Based on statistical analysis, the age variable will be divide into ages 41-50 years, 51-60 years and, 61-70 years. The calculation results get a sample size for men are 16 people and women 17 people for each age group (41-50, 5160 , and $61-70$ years), so that the sample needed is 33 people for three age groups, therefore a total of 99 people needed. Methods and Data Collection
Techniques are the subject selection and the signing of informed consent.

Researchers then conduct examinations. After that, subjects underwent spirometry and chest expansion tests and the results were interpreted. If there are normal spirometry and chest expansion values after converting grades from the Indonesian pneumobile team, the subject is given education on how to conduct PCF examination through video as a lesson. Finally, all subjects carry out an PCF check. Statistical analysis was done using SPSS version 20.0 .

We measure the mean for quantitative data with normal distribution, and for not normal distribution we measure the median. For categorical data we measure the frequency and the percentage of frequency. Statistical analysis using multivariate, for numerical data using independent $t$ - test if the data qualifies and Mann Whitney if not qualifies. Categorical data using chi-square for the tables and Fisher if not qualifies. The threshold value is set in $\mathrm{p}<0.05$.

\section{RESULT}

The research was conducted at the Polyclinic of the Cipto Mangunkusumo National Center General Hospital (RSUPNCM) Jakarta General Hospital after receiving a letter of approval from the research ethics committee (Letter number: 0263/ UN2.F1/ ETIK/ 2018) conducted from August to October 2018 with Research subjects are middle adulthood and late adulthood who have met the inclusion and exclusion criteria based on history taking and physical examination and explained and if they are willing to participate in the study. The subject is asked to sign an informed consent. 
Each subject was given an oral explanation and shown using video media how to measure PCF appropriately. Subjects took measurements three times with a break of at least two minutes at each measurement interval. The total number of subjects from an affordable population that met the inclusion and exclusion criteria determined in this study were 99 subjects. The measurement of the PCF value is carried out according to the procedure that has been described in the research method.

In the implementation of the number of research subjects who met the inclusion and exclusion criteria and were agree to participate in the study were 99 people. The subjects of this study determined 48 male and 51 female. The subjects of this study obtained an age with an average value of $55.81 \pm 8.84$ years, with an age range from 41-70 years based on the methodology categorized into ages 41 50 years there were 33 subjects, ages at 51-60 years there were 33 subjects, and aged 61-70 years there were 33 subjects, according to the proportional consecutive sampling method to get the equivalent of 33 people per age category. The number of female subjects was 17 subjects and men were 16 subjects for each specified age category. Subject height in centimeters obtained average of $159 \mathrm{~cm}$ with a range of 141 to $175 \mathrm{~cm}$. The mean BMI of the study subjects was $25.28 \pm 3.56 \mathrm{~kg} / \mathrm{m}^{2}$ (overweight). A history of smoking was found in 20 subjects with a prevalence of $20.2 \%$. In this study, the proportion of sex divided by each group of male as many as 48 research subjects and female group as much as 51 research subjects.
Table 1. Demographic of research subjects

\begin{tabular}{lc}
\hline \multicolumn{1}{c}{ Characteristics } & $\mathrm{n}(\%)$ \\
\hline Sex & $48(48.5)$ \\
Male & $51(51.5)$ \\
Female & \\
Age (years) & $33(33.3)$ \\
$41-50$ & $33(33.3)$ \\
$51-60$ & $33(33.3)$ \\
$61-70$ & \\
Height (cm) & $9(9.1)$ \\
$140-149$ & $41(41.4)$ \\
$150-159$ & $43(43.4)$ \\
$160-169$ & $159 \mathrm{~cm}(141-175 \mathrm{~cm})$ \\
Height (Median) & $25.28 \mathrm{~kg} / \mathrm{m}^{2} \pm 3.56 \mathrm{~kg} / \mathrm{m}^{2}$ \\
BMI
\end{tabular}

BMI : Body Mass Index

Obtained the median PCF for males aged 41-50 years is 465 (330-540) L / min, ages 51-60 years are 405 (315-490) L / min, and 61-70 years are 352.5 ( 290-520) L / min while in female groups the median PCF age $41-50$ years is 360 (290425) L / min, age 51-60 years is 340 (190-420) $\mathrm{L} / \mathrm{min}$ and age $61-70$ years is 330 (245-460) $\mathrm{L} / \mathrm{min}$. Obtained the median value of the PCF measurement results is statistically significantly greater in each age group in the group of men compared to women at the age of 41-50 years and 51-60 years $(p<0.05)$, but at the age of 61 years and over there was a decrease in the PCF value where the median value of the PCF results for men was not significantly different from women $(\mathrm{p}>0.05)$.

Based on statistical analysis, height variables were simplified into several categories with an area span of ten centimeters. The height value 
in this study obtained a range of height 140-179 $\mathrm{cm}$. Research subjects with height 140-149 cm have nine subjects, body height $150-159 \mathrm{~cm}$ have forty-one subjects, subjects with height 160- 169 $\mathrm{cm}$ have forty-three subjects, and height 170- 179 cm has six subjects.

Table 2. PCF categorized by sex and age

\begin{tabular}{|c|c|c|c|c|c|c|c|}
\hline \multirow{4}{*}{ Age } & \multicolumn{6}{|c|}{ Sex } & \multirow{4}{*}{$\begin{array}{c}\mathrm{P} \\
\text { (Mann Whitney) }\end{array}$} \\
\hline & \multirow{2}{*}{\multicolumn{3}{|c|}{$\begin{array}{l}\text { Men } \\
\text { PCF }\end{array}$}} & \multirow{2}{*}{\multicolumn{3}{|c|}{$\begin{array}{l}\text { Woman } \\
\text { PCF }\end{array}$}} & \\
\hline & & & & & & & \\
\hline & Median & Min & Max & Median & Min & Max & \\
\hline $41-50$ & 465 & 330 & 540 & 360 & 290 & 425 & 0.001 \\
\hline $51-60$ & 405 & 315 & 490 & 340 & 190 & 420 & 0.002 \\
\hline $61-70$ & 352.5 & 290 & 520 & 330 & 245 & 460 & 0.08 \\
\hline
\end{tabular}

*PCF:Peak Cough Flow

Obtained PCF value in the group height 140-149 $\mathrm{cm}$ is 320 (270-390) L/ minute, height $150-159$ $\mathrm{cm}$ is 345 (190-540) L/ minute, height 160-169 $\mathrm{cm}$ is 410 (290-540) L/ min, and height 170-179 $\mathrm{cm}$ is 460 (405-520) L / min. Subject obtained greater PCF value at a higher height.

Table 3. PCF categorized by Height and it's correlation

\begin{tabular}{ccc}
\hline Characteristics & $\mathrm{n}(\%)$ & $\begin{array}{c}\text { PCF } \\
(\text { minimum - } \\
\text { maximum })\end{array}$ \\
\hline Height $(\mathrm{cm})$ & $9(9.1)$ & $320(270-390) \mathrm{L} /$ \\
$140-149$ & $41(41.4)$ & $345(190-540) \mathrm{L} /$ \\
$150-159$ & minute \\
$160-169$ & $43(43.4)$ & $410(290-540) \mathrm{L} /$ \\
& & minute \\
$170-179$ & $6(6.1)$ & $460(405-520) \mathrm{L} /$ \\
& & minute \\
\hline
\end{tabular}

*PCF:Peak Cough Flow
The variable height of men and women influences the PCF value with weak correlation strength, but the correlation's strength is weaker in the female sex.

Table 4. Correlation between PCF with Height

Correlation
strength $(r)$

\begin{tabular}{ccc}
\hline $\begin{array}{c}\text { Height } \\
\text { (male) }\end{array}$ & 0.316 & 0.029 spearman \\
$\begin{array}{c}\text { Height } \\
\text { (female) }\end{array}$ & 0.295 & 0.036 pearson \\
\hline
\end{tabular}

*PCF:Peak Cough Flow 
Table 5. PCF categorized by Age

\begin{tabular}{|c|c|c|c|c|c|}
\hline \multirow{2}{*}{ Age } & \multicolumn{3}{|c|}{ PCF } & \multirow{2}{*}{$\begin{array}{c}\mathrm{p} \\
\text { (Kruskall Wallis) }\end{array}$} & \multirow{2}{*}{$\begin{array}{c}\mathrm{P} \\
\text { (Mann Whitney) }\end{array}$} \\
\hline & Median & Min & Max & & \\
\hline $41-50$ & 390 & 290 & 540 & 0.008 & Ref \\
\hline $51-60$ & 360 & 190 & 490 & & 0.073 \\
\hline $61-70$ & 340 & 245 & 520.0 & & 0.002 \\
\hline
\end{tabular}

PCF:Peak Cough Flow

From the results of the study, the median PCF at age 41-50 years was 390 (290-540) L / min, age 51-60 years was $360(190-490) \mathrm{L} / \mathrm{min}$ and at age 61-70 years was 340 (245-520) L / minute. Based on the analysis found a statistically significant relationship between the age variable and the PCF value, i.e. the higher the age, the lower the PCF value obtained $(p<0.05)$ and there was a significant decrease in the PCF value at age 6170 years compared to age $41-50$ years $(\mathrm{p}<0.05)$.

\section{DISCUSSION}

The subjects in this study were men or women between the ages of 41 to 70 who had healthy respiration in the RSUPNCM environment taken by consecutive sampling. The number of samples is 99 people. The subjects' characteristics based on the sex that has been determined were 48 men (48.5\%) and 51 women (51.5\%) with ages up to 70 years, with an average value of $55.81 \pm 8.84$ years. Based on the report of the Central Statistics Agency (BPS) in 2010 in Indonesia there were 61 million people aged over 40 years with a percentage of 25.82 of the total population of Indonesia, and at the age of 41-70 years it was found that gender characteristics $49.83 \%$ were women and $50.17 \%$ were male, which did not match the sex characteristics of the study subjects. But for body mass index, the characteristics are following the population with body weight of 40 $\mathrm{kg}$ to $99 \mathrm{~kg}$ with an average value of $63.13 \mathrm{~kg}$ and the category of BMI (Body Mass Index) $17.3 \mathrm{~kg} /$ $\mathrm{m} 2$ to $36.1 \mathrm{~kg} / \mathrm{m}^{2}$ with an average $25.28 \mathrm{~kg} / \mathrm{m}^{2}$ $\pm 3.56 \mathrm{~kg} / \mathrm{m}^{2}$ (overweight). This is the following research by Wang et al. (2016), which states that most are overweight in subjects aged 40-70 years, with a prevalence of overweight $42.2 \%$. The reason for the researchers to take the age limit from 41 to 70 years is based on previous research conducted by Freitas et al (2010) in Brazil for older adults with age over 60 years and there is no research yet on the value of the PCF in healthy middle- age adult. Based on the understanding by Hurlock (2001), that middle adulthood is between 41 and 60 years of age, and late adulthood is 61 years of age until death, but to be taken is between 41-70 years due to normal spirometry values for Indonesians (pneumomobile) only until the age of 70. Determinating number of age and sex proportions in this study was not adjusted to national proportions, because it was designed to obtain normal range values for each category. For the sex of the study subjects, each was determined as many as 48 men and 51 women from a total of 99 research subjects. This is consistent with the PCF study by Cardoso (2012) with more female than male subjects $(252: 232) .{ }^{18}$ This is not following the 2010 Central Statistics Agency (BPS) report that Indonesia's male population is 119 million and 118 million women with a sex 
ratio of 101 which means there are 101 men for every 100 women and the 2013 BPS report that states that $50.25 \%$ of Indonesia's population is male and $49.75 \%$ is female. At the age of $41-70$ years, it was found that sex characteristics were $49.83 \%$ female and $50.17 \%$ male. $^{23}$

Subjects in this study found that 20 people had a history of smoking, with a prevalence of $20.2 \%$ of the total sample. The Sirait study (2002) says that at the age of 40-44 years in Indonesia $74.4 \%$ of men smoke and will decrease to $64.7 \%$ at 65 69 years. A history of smoking was not included as a study exclusion criterion due to trying to obtain a sufficient number of male samples for the 41-70 age range and because the subjects of this study were middle and late adulthood with healthy respirations screened by spirometry examination. All subjects who participated in this study were explained the research in groups or individually. After that the subjects were screened by spirometry examination. If normal spirometry results are obtained without obstruction or restrictions adjusted for the value of Indonesian pneumomobile results based on age, sex and height. Then the subject is to be further examined, namely the PCF measurement.

In male gender PCF values are obtained with 290 $\mathrm{L} / \mathrm{min}$ to $540 \mathrm{~L} / \mathrm{min}$ and in women obtained range of $190 \mathrm{~L} / \mathrm{min}$ to $460 \mathrm{~L} / \mathrm{min}$. Table 2 shows the statistically significant difference in PCF values between men and women. The obtained mean value of the PCF measurement results is statistically more significant in the age group 41-50 years and 51-60 years in the group of men compared to women, but at age 61 years and over there is a decrease in the value of the PCF where the median value of the PCF men are not significantly different from women.
This is consistent with research by Freitas et al (2010) saying the average PCF value in healthy late adulthood in Brazil is $309.2 \mathrm{~L} / \mathrm{min}$ in women and $434.4 \mathrm{~L} / \mathrm{min}$ in men where the PCF value in men is significanctly greater than in women ( $p$ 0.001). 5 Research by Cardoso (2012) also said PCF values in healthy young adults (1840 years) Caucasian race in Brazil in women between 242-355 L / min and in men between 316-499 L / min. ${ }^{18}$ Research by Fauzan (2016) says the PCF value in young adults in Indonesia (Mongoloid race) in males is between 463 - 607 $\mathrm{L} / \mathrm{min}$ and in women 366 - $472 \mathrm{~L} / \mathrm{min}$. Moreover, that type of sex is a factor that influences the PCF value. ${ }^{20}$ This is because women have the capacity of a lung capacity $20-25 \%$ smaller than men. Research by Yawata (2017) says there are significant differences in examining lung function, respiration muscle strength and chest expansion in men compared to women $(p<0.05)$. This happens because the value of height and weight of men is significantly greater than women. Height and weight are factors that affect respiration function and respiration muscle strength, also affect chest expansion. Pulmonary function, respiratory muscle strength and chest expansion are all factors that influence the inspiratory, compressive, and expulsive phases of the coughing process so that the ability to cough in women is lower than men..$^{25}$

Based on this study's results, it was found that subjects with higher height had a greater PCF value. It was also found that male and female height variables affected PCF values with weak correlation strengths but weaker correlation strengths on female height.

This is consistent with research by Lee et al. (2015), which says the average PCF value of 
Caucasian races in England is $652 \mathrm{~L} / \mathrm{min}^{24}$ Research by Fauzan (2016) says the PCF value in young adults in Indonesia (Mongoloid race) is around 310- $645 \mathrm{~L} / \mathrm{min}$ with a mean of 477.17 $\mathrm{L} / \mathrm{min}$ and that the higher height correlates with, the greater PCF (Correlation coefficient: 0.741). ${ }^{20}$ In the two races, there was a significant difference in median height in England (mean $177.6 \mathrm{~cm}$ ) and in Indonesia (mean $158 \mathrm{~cm}$ ).

The normal PCF value in Indonesia tends to be lower than other reference PCF values from England. This is because of the higher height factor in England compared to Indonesians. This may be influenced by the influence of the vital lung capacity which is physiologically affected by height. The higher the height, the higher the vital lung capacity value. ${ }^{22}$ So that this will affect one's inspiration, which will affect cough as assessed by the PCF.

Table 5 shows a statistically significant relationship between the age variable and the PCF value, i.e., the higher the age, the lower the PCF value obtained and there is a significant decrease in the PCF value at age 61-70 years (older adults) compared to 4150 years of age (middle adulthood). The median PCF for ages 41- 50 years is $390 \mathrm{~L} / \min (290-540$ $\mathrm{L} / \mathrm{min}$ ), 51-60 years old is $360 \mathrm{~L} / \mathrm{min}(190-490$ $\mathrm{L} / \mathrm{min}$ ) and the age of $61-70$ years is $340 \mathrm{~L} / \mathrm{min}$ minutes (245- $520 \mathrm{~L} /$ minute).

Research by Cardoso (2012) says the PCF value in healthy young adults (18-40 years) of Caucasian race in Brazil is between 240-500 L / min, and the results decrease with age. ${ }^{18}$ Fauzan (2016) says the PCF value in adults young people in Indonesia (Mongoloid race) range from 310-645 $\mathrm{L} / \mathrm{min}$ and a decrease in PCF value is obtained with increasing age. ${ }^{20}$
Significant reductions in PCFs above 50 years of age are considered for the following reasons. In middle and late adulthood, lung parenchyma and chest wall become less elastic due to an increase in collagen, which is more rigid and reduced elastin. Also, the ability of microsilia to secrete decreases and the strength and endurance of respiration muscles decreases due to type IIa muscle atrophy. Type I and IIb muscles are more dominant, indicating the decondition of respiratory, especially in the abdominal muscles. Diaphragm strength decreases $25 \%$ in healthy late adulthood compared to young adults, accompanied by weakening of the muscles of the abdominal expiration and chest wall so that it cannot empty the lungs in normal breathing due to reduced maximal inspiratory pressure (from 20 years old) and expiration (from 50 years old). This causes a decrease in the lung's vital capacity so that the ability to cough is reduced. ${ }^{2,4-6}$

In this study, limitations are samples of subjects who, although they are following the references, are still not representative enough to represent in general data for middle and late adulthood populations in Jakarta and Indonesia because they do not represent equally in each region in Jakarta and Indonesia

Strengths in this study include that this study's results have accurate results for healthy subjects because they are based on spirometry examinations, thereby getting rid of obstructive and restrictive respiratory system disorders.Also, this is the first study in assessing the range of PCF values in healthy middle adulthood and late adulthood in Indonesia (Mongoloid race). 


\section{CONCLUSION}

From our research, we found that the PCF value in healthy middle adulthood ranges from 190$540 \mathrm{~L} /$ minute with the median value of age 4150 years $465 \mathrm{~L}$ / minute, age 51-60 years $405 \mathrm{~L}$ / min and in healthy late adulthood, PCF values ranging from 245-520 L / minute with median values $352.5 \mathrm{~L} / \mathrm{min}$. Based on sex, men have a higher PCF value compared to women, but at the age of 61 years and over, there is a decrease in the value of the PCF where the median value of the PCF results of men is not significantly different from women. The higher the age, the lower the PCF value obtained, and there is a statistically significant decrease in the value of the PCF at the age of 61-70 years compared to the age of 4150 years. Based on height, subjects with higher height tend to a higher PCF value and height will affect the PCF value.

\section{REFERENCES}

1. Chang AB. The physiology of cough. Pediatric respiratory review. 2006;7:2-8.

2. Hazzard W, et al. HAZZARD'S GERIATRIC MEDICINE AND GERONTOLOGY Sixth Edition. The McGraw-Hill Companie;.2009. pp. 983-1003.

3. Sherwood L. Respiratory system. In: Brooks/ Cole B, editor. Human physiology from cells to system. 7th ed. 2010.

4. Lesauskaite V, Ebejer M. Age-Related changes in the respiratory system. Maltese Medical Journal, 1999; 11(1,2): 25
5. Freitas F, et al. Relationship between cough strength and functional level in elderly. Rev Bras Fisioter. 2010;14(6):470-75.

6. Haas C, Loik P, Gay S. Airway Clearance Applications in the Elderly and in Patients With Neurologic or Neuromuscular Compromise. Respiratory Care. 2007;52(10):1362-4.

7. Chung K, Widdicombe J, Boushey H. Cough: Causes, Mechanisms and Therapy. Oxford : Blackwell ltd; 2003.

8. Canning B, Chang A. Anatomy and Neurophysiology of Cough CHEST Guideline and Expert Panel Report. CHEST. 2014; 146: 1633-48.

9. Castro RT, Vilaro J, Uribe RV, Monge G, Aviles P, Suranyi C. Use of air stacking and abdominal compression for cough assistance in people with complete tetraplegia. Spinal cord. 2014;10(1) :1-4

10. NHANES. Respiratory Health: Spirometry Procedures Manual. USA:CDC;2008.

11. Tantisuwat A, Thaveeratitham P. Effect of Smoking on ekspansi dada, lung function, and Respiratory Muscle Strength of youths. J. Phys. Ther. Sci.2014;26:167-70.

12. Haas A, Pineda H, Haas F, Axen K. Pulmonary therapy and rehabilitation: principles and practice. California:Wiliam \& Wilkins;1979.

13. Moll, JMH and Wright, V. An objective clinical study of ekspansi dada. Annal of the Rheumatic Disease. 1972;3191:1-8.

14. Hurlock E. Psikologi Perkembangan. 5th ed. Jakarta: Erlangga; 2001.

15. Adedoyin R,. Reference Values for Ekspansi dada among Adult Residents in Ile- Ife. J Yoga Phys Ther. 2012; 2(3):1-5. 
16. Paraswari N, et al. Perbedaan ekspansi paru antara lansia yang rutin melakukan senam lansi dengan lansia yang rutin melakukan olahraga tai chi di kota Bandung. Prosiding Penelitian Sivitas Akademika Unisba. Bandung: UNISBA;2014.

17. Sandhu P, Bajaj D,Mehta K. Correlation of peak expiratory flow rate with age and anthropometric parameters in elderly ( $>65$ years). Nati J Physio Pharm Pharmacol. 2016: $6(1): 89-92$.

18. Cardoso et al. Evaluation of peak cough flow in Brazilian healthy adults. International Archives of Medicine. 2012; 5:25.

19. Haas A, Pineda H, Haas F, Axen K. Pulmonary therapy and rehabilitation: principles and practice. California : Wiliam \& Wilkins: 1991

20. Fauzan A . Faktor-Faktor yang mempengaruhi Nilai Arus Puncak Batuk pada dewasa muda sehat Indonesia. Jakarta: Program Studi Ilmu Kedokteran Fisik dan Rehabilitasi FKUIRSUPN Cipto Mangunkusumo ; 2016.
21. Suarez AA, et al. Peak Flow and Peak Cough Flow in the Evaluation of Expiratory Muscle Weakness and Bulbar Impairment in Patients with Neuromuscular Disease. Am. J. Phys. Med. Rehabil. 2008;81(7): 506-11.

22. Wang L. Semi-recumbent position versus supine position for the prevention of ventilator-associated pneumonia in adults requiringmechanical ventilation (Review). Cochrane Database of Systematic Reviews 2016, Issue 1. Art, No: CD009946.

23. Badan Pusat Statistik. Sensus Penduduk 2010. Jakarta; BPS: 2010.

24. Lee K. The Intensity of Voluntary, Induced, and Spontaneous Cough. CHEST. 2015; 148(5): 1259 - 67.

25. Yawata A. Voluntary cough intensity and its influencing factors differ by sex in community-dwelling adults. Ther Adv Respir Dis. 2017 ; 11(12): 427-33. 